\title{
Corrigendum: A brain-sparing diphtheria toxin for chemical genetic ablation of peripheral cell lineages
}

Mafalda M.A. Pereira, Inês Mahú, Elsa Seixas, Noelia Martinéz-Sánchez, Nadiya Kubasova,

Roksana M. Pirzgalska, Paul Cohen, Marcelo O. Dietrich, Miguel López,

Gonçalo J.L. Bernardes \& Ana I. Domingos

Nature Communications 8:14967 doi: 10.1038/ncomms14967 (2017); Published 3 Apr 2017; Updated 17 May 2017

The financial support for this Article was not fully acknowledged. The Acknowledgements should have included the following:

${ }^{* * *}$ Human Frontiers Science Program (HFSP) funds the labs of A.I.D. and P.C. $\left.{ }^{* * *}\right]$.

(c) This work is licensed under a Creative Commons Attribution 4.0 International License. The images or other third party material in this article are included in the article's Creative Commons license, unless indicated otherwise in the credit line; if the material is not included under the Creative Commons license, users will need to obtain permission from the license holder to reproduce the material. To view a copy of this license, visit http://creativecommons.org/licenses/by/4.0/

(C) The Author(s) 2017 